\title{
THE LOGICAL PROBLEM OF EVIL IN ISLAM AND CHRISTIANITY: A Comparative Approach in the Thought System of Ibn Sînâ and Richard Swinburne
}

\author{
Mukhammad Zamzami \\ Universitas Islam Negeri Sunan Ampel Surabaya, Indonesia \\ Jl. A. Yani 117 Surabaya Jawa Timur 61257 \\ e-mail: m.zamzami@uinsby.ac.id
}

\author{
Abdullah HosseiniEskandian \& Aabas Aabaszadeh \\ University of Tabriz, East Azerbaijan, Iran \\ St. 29 Bahman Boulevard, Tabriz, Iran \\ e-mail: hosseinieskandianabdullah@gmail.com \\ Muktafi \\ Universitas Islam Negeri Sunan Ampel Surabaya, Indonesia \\ Jl. A. Yani 117 Surabaya Jawa Timur 61257 \\ e-mail: muktafi.sahal@uinsby.ac.id
}

\begin{abstract}
The study of the ideas of Ibn Sînâ and Richard Swinburne as the pioneers of Islamic philosophy and the West philosophy, and on the other hand, the existing scholastic and ideological differences, is something that can help us to become more familiar with the thoughts of these philosophers and intellectual differences and similarities. In this research, with the analytical method and using the necessary documents, the nature, types, and solutions of evil in the thought of Ibn Sînâ and Swinburne are examined, and also the two philosophers' thoughts about evil are compared. Both philosophers have considered the existence of evil not in contradiction with the divine attributes, but it is necessary for the acquisition of good.
\end{abstract}

\begin{abstract}
Abstrak: Kajian terhadap pemikiran Ibn Sînâ dan Richard Swinburne tentang kejahatan menjadi menarik untuk dianalisis karena perbedaan horizon berpikir keduanya. Jika Ibn Sînâ mewakili tradisi filsafat Islam, maka Richard Swinburne dianggap mewakili filsafat Barat kontemporer. Dalam artikelini, penulis menganalisis dari dokumen kepustakaan yang diperlukan, baik tentang sifat, jenis, dan solusi atas kejahatan menurut pandangan Ibn Sînâ dan Swinburne. Bagi kedua filsuf, eksistensi kejahatan tidak bertentangan dengan sifat-sifat ilahi.
\end{abstract}

Keywords: evil, Ibn Sînâ, Richard Swinburne, Divine attributes, world of creation 


\section{Introduction}

One of the problems that is always expressed as a parallel to denying the existence of God and challenging His attributes or believing in duality is the problem of evil. Various thinkers and sages from the time of ancient Greek philosophy have discussed and commented on the problem of evil. In Islamic philosophy, Ibn Sînâ (980-1037 AD) is one of the philosophers who has discussed and researched evil in his works. Ibn Sînâ considers God to be an absolute good that is not issued except goodness from Him, and if something is considered as "evil", or does not exist at all (it is non-existent) or that our view considers it evil but in fact it is good, not evil. Ibn Sînâ considers the existence of evil as a necessity of the essence of this world and considers it as an important factor in achieving charity. ${ }^{1}$ In Western philosophy, on the other hand, Richard Swinburne (an English philosopher born in 1934) is one of the thinkers who has discussed and commented on this with a special influence on Christian theology. Swinburne accepts the existence of evil in a minimal sense and considers this minimal role necessary for the existence of a good system, he also believes that if the problem of evil is properly understood, not only will it not be a factor in the direction of godliness, but with them, the existence of God can be better understood. ${ }^{2}$

Investigating the nature of evil in Ibn Sînâ's thought as a Muslim philosopher and one of the most influential Islamic philosophers, on the other hand, Swinburne, as one of the greatest theologians of Christianity today, is something that can clarify the differences and intellectual similarities of these philosophers according to religious and scholastic principles.

The problem of evil is one of the long-standing cases that has been studied and researched throughout the history of thought. The oldest books that mention the existence of evil can be considered Rig Veda in Hinduism and Avesta in ancient Iran. Also, in the Testaments and the Holy Quran, many verses indicate the existence of evil.

Philosophically, the problem of evil, since it is related to the issue of existence and non-existence, was discussed in Greek philosophy by scholars such as Plato, Aristotle, and Xenon. In Islamic philosophy, great philosophers such as al-Fârâbî, Ibn Sînâ, Suhrawardî al-Maqtûl, Mulla Sadra and other Islamic sages have paid attention to the problem of evil and have discussed it in their works.

In modern times, the problem of evil is one of the most important cases in theology and philosophy, as Spinoza states: "In contemporary times, the problem of evil has provided the most serious rational critique of arguments based on belief in God or the absoluteness

${ }^{1}$ Ayman Shihadeh, "Avicenna's Theodicy and al-Râzî's Anti-Theodicy," Intellectual History of the Islamicate World 7, no. 1, (2019): 61-63. DOI: https://doi.org/10.1163/2212943X00701004.

${ }^{2}$ Raphael Lataster, "On Richard Swinburne and the Failings of Christian Theistic Evidentialism," Literature and Aesthetics 26, (2016):. 32-34. 
of its attributes, the perfection of the sacred essence. The diversity of the debate has led to many theologians, philosophers, and thinkers in the East and the West addressing this issue. The existence of shortcomings, distortions, all kinds of disasters and injustices in the world of human evolution raises questions about the originality of these matters". ${ }^{3}$

Thus far, no research has been done that independently examines and compares the thoughts of Ibn Sînâ and Swinburne about evil, and only some articles compare the thoughts of these philosophers with other thinkers. Like a study and comparison of evil from the perspective of Augustine and Ibn Sînâ, written by Khalil Soultan al-Qaraei et al. which, there is no comprehensive discussion about Ibn Sînâ's thoughts on the evil and from Ibn Sînâ's point of view, there is no comprehensive discussion about the types of evil and its solutions. Also, in the article "comparative study of the problem of evil from the point of view of Suhrawardi and Swinburne, written by Maryam Solgi there is no discussion about the nature of evil and its justification from the perspective of Swinburne.

The initiative of this research is to study and compare the thoughts of Ibn Sînâ and Swinburne about evil for the first time and then a comprehensive study of the thoughts of these philosophers about the nature, types, and solutions of evil. Man has long been faced with these questions about the events around him, what is really evil, how did evil come into being, or does it exist at all, and who created evil? In addition to these questions, theists face other questions that, in a different way, can contradict their religious principles, and how is it possible that evil is issued from God, the Absolute Benefactor? The existence of these questions has long been a source of thought and discussion among various thinkers.

\section{Methodology}

In this research, an attempt is made to study and compare evil in the thought of Ibn Sînâ and Richard Swinburne by using analytical capacities as well as citing reliable references, and an attempt is made to answer these questions; what description did Ibn Sînâ and Swinburne have of evil, is evil non-existent or existential, are the evils in contradiction with the divine attributes, can the existence of the evils be considered as a violation of the good system from the point of view of Ibn Sînâ and Swinburne, what are the types of evil, what solutions did Ibn Sînâ and Swinburne state to solve the problem of evil, and what are the similarities and differences about evil in the thought of Ibn Sînâ and Swinburne? It is these questions that will be analyzed in this article.

${ }^{3}$ Baruch Spinoza, Ethics, trans. by Mohsen Jahangiri (Tehran: University Publishing Center, 1997), 82. 


\section{Results and Discussion}

\section{Approaches to the Nature and Problem of Evil}

According to Ibn Sînâ's view, some things are permissible, their existence is free from any evil, corruption, and others, and others are things that may not be perfected unless they are subjected to evil when the movements and collisions of the movements. Among these types, there are other matters that are either absolute or evil and when pure God is the source of the existence of good and virtuous, the existence of the first type is obligatory, such as the existence of rational essences and the like. Also, the existence of the second type is obligatory because in not creating much good, there is a lot of evil due to avoiding a little evil. ${ }^{4}$

Ibn Sînâ believes that since the existing world was issued by God, who is the cause of causes, then the most perfect world will be possible, and since God is pure good, then the world is full of goodness. He states: "The essence of the Almighty is the cause of the export of things, not something outside of His essence, and His essence is the cause of the system of goodness, and everything that originates from His essence must be in accordance with His essence, and in order for God's essence to be good, it must be good. Therefore, everything must be regular and good because it does not contradict the essence of transcendence".

Ibn Sînâ in the definition of evil states: "Evil is inherently non-existence and not every non-existence. Rather, it is the absence of perfection to which something in its kind or nature is appropriate ${ }^{6}$ and also in al-Shifâ' in the definition of evil, he states that evil is a non-existent thing that has no essence but is lack of essence or imperfection for essence. ${ }^{7}$ Therefore, from Ibn Sînâ's point of view, evil is a non-existent thing that does not exist and its absence is the same as the lack of perfection that exists in the essence of everything.

In addition to defining evil as non-existent, Ibn Sînâ analyzes his claim regarding some of its instances. In his view, evil is used in two senses, first to indicate imperfections such as ignorance, inability and imperfection in creation; and second things that do not exist externally but are perceived, such as pain and sorrow. There can be no existential aspect for the evil. Ibn Sînâ states:

"Based on the fact that the beings of the universe are created according to the knowledge of God, absolute good, naturally the system of existence will be the best possible system.

But this world has been questioned due to its shortcomings and evils, and doubts have

\footnotetext{
${ }^{4}$ Ahmad Beheshti, Tajrîd (Qom: Book Garden Institute, 2010), 360.

${ }^{5}$ Ibn Sînâ, al-Ta lîqât, ed. 'Abd al-Rahmmân Badawî (Qom: Islamic Media School, 1982), 159.

${ }^{6}$ Ibn Sînâ, al-Najâh, ed. Mohammad Taghi Daneshpajooh (Tehran: University of Tehran Press, 1986), 670.

7 Ibn Sînâ, al-Shifâ' (Tehran: Nasir Khosrow Publications, 1985), 381.

${ }^{8}$ Ibn Sînâ, al-Ishârât wa al-Tanbîhât, Vol. 2 (Qom: Ayatollah Marashi Najafi Library, 1993), 95.
} 
arisen in the minds of human beings about the goodness of this system. On the other hand, among the attributes of God, two attributes, which are justice and wisdom, have been confronted with doubts due to the existence of evil. God's righteousness means that He does not neglect the merits of any creature and gives everyone what s/he deserves, and the meaning of being wise means that in the system of creation, there is a good and righteous system and the best system is possible. Common problems about God's justice and wisdom, the existence of misery, and in other words, the problem of evil, how evil is issued from pure good". ${ }^{8}$

According to the proposition that God is absolute good and always wants good for His servants, the impression is created in the mind of man that he should be in absolute joy and happiness, but when he looks at his situation and looks at his true state, finds that in the true sense of the word is not in absolute happiness and blessings, and has a life of ups and downs, and this has led to the questioning of the good system and has caused doubts about it. In the meantime, the two attributes of justice and divine wisdom have become very suspicious in spite of human misfortunes in this world, because some people consider the existence of these misfortunes and misery to be contrary to divine wisdom, and on the other hand, the existence of all these problems has been avoided. Knowing justice and this has caused doubt and objection about the divine attributes, the source of which is related to the problem of evil in the world, and in fact this evil has required discussion of divine attributes and has attracted the attention of philosophers such as Plato, Aristotle, al-Fârâbî, Ibn Sînâ, and etc.

According to Ibn Sînâ, God is the pure giver, the giver is the one who expresses and deserves what he deserves, without expecting any change or reward, and a being who is pure good is impossible to create evil or export evil, so evil cannot be attributed to God.

Ibn Sînâ does not consider man's view of evil to be true, and believes that it is the desirability of an object in the eyes of man that determines whether it is good or evil for man, and if the object is beneficial to man, it is good, and if has a loss, considers it evil. Therefore, the existence of evil depends on the reputation of man, and the desirability of the object determines its goodness or evil, and this idea of man often encounters errors and problems and makes mistakes in cognition. Ibn Sînâ states:

"All the creations of the almighty Creator are inherently good, and God, who is the absolute good, has created them inherently good, and there is no evil in the creations of the almighty God, but it is the superficial view of human beings that considers things evil". 9

Therefore, from Ibn Sînâ's point of view, the world has abundant goodness from

${ }^{9}$ Ibn Sînâ, al-Shifâ', 419. 
the absolute good, and all the goodness of the world is created by Him, and it is the mind of man who fails to identify correctly and considers things evil.

According to Swinburne, the existence of evil is a necessary thing for a good system, and without the existence of evil, there will be no good system, and evil is necessary for the existence of this world. ${ }^{10}$ Swinburne states:

"Henceforth, when I speak of the actions of the perpetrators and their characteristics, and when I speak of the state of affairs in general, I put the good versus the bad. I use the state of affairs in its causal sense, that is, the events that happen to people, as well as their intentional actions. Sufferings and other afflictions and situations are bad, and it does not seem right to call them evil, even if the factor that caused it happen has been committed. Although the issue we are dealing with here is called the "problem of evil", it is in fact a matter of bad situations, as it is not permissible for a factor that can prevent them from occurring". ${ }^{11}$

Swinburne does not accept the non-existence of evil and believes that evil is the absence of a state of abundant goodness, the removal of which makes it possible for charities to exist. In fact, the absence of good in the existence and essence of any object can be an excuse for its evil. On the other hand, Swinburne considers any factor that prevents a person from achieving good to be evil because it also hinders the lack of goodness and the acquisition of goodness. ${ }^{12}$

According to Swinburne, suffering and other false traits and desires are simply due to the lack of some kind of goodness; but pain is not just a lack of pleasure and evil deeds, it is not just a lack of good deeds, and the world can be depicted without suffering and evil. This is why his view of the nature of evil is at odds with its non-existence. Swinburne states that the problem of evil is not a problem that is related to the lack of many good states, and that a large number of evils are positive because of the bad state, and that God can eliminate them if God wills. ${ }^{13}$

Swinburne believes that we should consider the good and bad of deeds in the case of the God of the universe in relation to the consequences of those deeds, because a phenomenon or thing may seem evil to us, but its essence is all good, and we be unaware of it. Therefore, we should not look at things with a superficial look, and perhaps the things that we consider

${ }^{10}$ David O'Connor, "Swinburne on Natural Evil from Natural Processes," International Journal for Philosophy of Religion 30, No. 2, (1991): 77-87. http://www.jstor.org/stable/40020283.

${ }^{11}$ Richard Swinburne, Providence and the Problem of Evil (Oxford: Clarendon Press, 1998), 3.

${ }^{12}$ Abdullah Hosseini Eskandian and Masoumeh Rajab Nezhadian, "Evil Thought and its Approaches with an Emphasis on Swinburne's Theodicy of Divine Justice," Metafizika 3, No. 4, (2020), 112.

${ }^{13}$ Brian Leftow, "Swinburne on Divine Necessity," Religious Studies 46, no. 2, (2010), 141-162. http://www.jstor.org/stable/25676934. 
evil are all good and blessed for us, and this is the result of an action or that phenomenon that determines being good and evil. So, God, who is absolute good, He always gives good to His servants and protects them from evil.

In the case of God, who is omnipotent, Swinburne states that likewise, absolute goodness cannot be defined in this way, for He often has an infinite range of actions at His disposal, and from whomever He chooses, one can still do better than It imagined his power. By the same token, any world full of intelligent creatures created by him is still conceivable that he can create a better world. In this case, nothing positive can be said about what an absolute good God can do.

Swinburne believes that God, because He is the absolute good, always receives good from Him and cannot be considered the source of evil, and states that I accept that the omnipotent being can prevent the occurrence of any bad state in terms of reasonable refusal may prevent it. But I do not accept that a being who is pure good should choose the same. A being who is pure good, if he allows a bad state to occur, should have the right to allow that bad state to occur. ${ }^{14} \mathrm{He}$ also states that God cannot accomplish many good things in the absence of bad things. The most obvious example of this rational restraint that God is responsible for is that God cannot give us free will, which means that we can choose between good and evil, without the natural possibility of doing evil. The fact that human beings have the ability to create important evils is a logical consequence of the fact that they have a free and responsible choice; even God cannot give us this choice without the possibility of obtaining evil. ${ }^{15}$

It is interesting to analyze here that Swinburne also believes the impossible is beyond the power of God, and that God, who is omnipotent, cannot do two impossible things, and that $\mathrm{He}$ is also unable to accomplish. It is also that it is not able to achieve, for example, two incompatible good things at the same time so that people can benefit from it. Swinburne states that it is logically impossible for God to create good by any morally permissible means other than allowing evil to be accomplished. For example, it is logically impossible for God to give us the free will to choose between good and evil, and at the same time to cause that we choose the good and it is logically impossible for God to achieve our good with such a free will, without the evil of a bad choice being realized. ${ }^{16}$

Swinburne considers the creation of impossible things to be outside the power of God, and by the same token believes that God is not the creator of evil, and that it is man

\footnotetext{
${ }^{14}$ Richard Swinburne, "Some Major of Theodicy," Daniel Howard-Snycer (ed.), The Evidertial Argument from Evil (Bloomington: Indiana University Press, 1996), 30.

${ }^{15}$ Richard Swinburne, Is There a God? trans. by Mohammad Javadan (Qom: Mofid University Press, 2002), 158.

${ }^{16}$ Richard Swinburne, Providence and the Problem of Evil (Oxford: Oxford University Press, 2008), 56.
} 
who, by abusing his free will, causes evil. And the things that we consider evil and attribute to God are inherently harmless and all good.

\section{Evil Types}

What is evident from Ibn Sînâ's system of thought is that evils are not on the same level and have different types according to the method of issuance and the source of issuance. Whether God, man or nature, can take different theological and philosophical approaches and provide a basis for discussion. Ibn Sînâ states:

"Evil has types that are sometimes called evil and it means a defect, and examples of this defect are: ignorance, weakness and ugliness, and sometimes it is referred to as evil and it means pain and sorrow, of course, pain and sorrow that to have that knowledge. Whether the cause is incompatible with good or the absence of good causes good and sometimes it is different from good and the one who suffers does not realize it like a cloud that casts a shadow and prevents the sun from shining on the creature in need of light". ${ }^{17}$

Ibn Sînâ considers evil to be limited to two parts, relative non-existence and essentially lacking in essence, and has said things about each of these types of evil that are an estimate of the specific ideas of his philosophical school.

Relative evil means the relation to being real; that is, it is a comparison in which the reality of an object depends on a series of conditions, and the meaning of being absolute is to be freed from a series of conditions. If we consider relativity in this sense, all material and natural things are relative in that they depend on a series of finite temporal and spatial conditions, and only in those conditions and depending on those conditions, they have their own reality. ${ }^{18}$ According to this view, evil is a relative thing and may be a phenomenon of evil for some people and the same phenomenon may seem good to others, and we should note that relativity is opposite to the truth.

It is clear from Ibn Sînâ's words that there is a logical difference between these two statements; the statement that "evil is not in the world" is a negative academic proposition of the simple type, while the statement that "evil in the world is of the type of non-existence" is a positive proposition of the compound type, and Ibn Sînâ means that evil is non-existent but it does not remove evil from the context of the system of possibility, because when it says evil in essence, it is non-existence, and its content is that evil is a phenomenon, but not from the type of existence, but from the type of non-existence, from the context of the world system through service. ${ }^{19}$ It was said that evil is non-existent, but could God have

${ }^{17}$ Ibn Sînâ, al-Najâh, 649.

${ }^{18}$ Ibn Sînâ, al-Shifâ', 358.

${ }^{19}$ Maryam Sadeghi, "The View of Three Muslim Wise Men on the Issue of Evil," Sinai Philosophy: Quarterly Journal of the Seventeenth Year, (2013). 
created this thing in such a way that it does not have this non-existent aspect? In response, it should be said that this non-existent aspect is inseparable from its essence. If fire wants to be fire, it must be melting, otherwise it is no longer fire. Ibn Sînâ states:

"If it is separated from this non-existent aspect, then it has become different from itself, as if fire has become non-fire". ${ }^{20}$

According to Ibn Sînâ, evil is a non-existent thing for which no essence or existence can be imagined. So evil cannot exist and the things we consider evil are in fact the estimation of our own thoughts and not the truth and essence of those things and if time pass it or if we pay attention to those matters with a deep look, we will realize its charity. The nonexistence of evil was first discussed in ancient Greek philosophy and later in Islamic philosophy by philosophers such as al-Fârâbî, Ibn Sînâ, and Mulla Sadra.

On the other hand, Ibn Sînâ considers evil to be a relative thing that is different for each person and may be a good phenomenon for one person and the same phenomenon as evil for another person..$^{21}$ In another classification, Ibn Sînâ has divided evil into essence and non-essence. In his view, evil in essence is the same as non-existence, but not every non-existence, but imperfection that is necessary for the type and nature of a thing, and evil without essence is something that destroys or deprives the deserving of these perfections. ${ }^{22}$ In fact, evil is a kind of obstacle to achieving perfection, and because it prevents a person from achieving charity, it is considered evil. It should be noted that any factor that prevents a person from achieving good, whether it is sin, lust, malice and anything else, is considered evil from Ibn Sînâ's point of view.

Evil either joins matter from the beginning, or matter is exposed to evil in later stages due to a side effect. Evil, which is related to matter itself, is evil that is attached to a particular substance in the first stage of creation, in such a way that some external factors join evil and replace it with a body or state that prevents the perfection of the specific talent of matter. And it suffers from the proper evil of the said perfection like a substance that comes from a human or a horse, whenever this substance is exposed to the causes and factors that make its temperament and its essence undesirable, it will no longer accept the shape and form appropriate to it, and as a result it will cause defects and ugliness in creation, and it is not that the actual cause of causes deprivation, but the material and the acceptor lack the talent of acceptance. ${ }^{23}$

${ }^{20}$ Amir Abbas Alizamani and Fateme Sadat Hashemi, "Augustine's Theory on the Problem of Evil and Its Critique from Ibn Sina's Perspective," Avicennian Philosophy 19, no. 54, (2016): 103-104.; Ibn Sînâ, al-Ishârât wa al-Tanbîhât, 328.

${ }^{21}$ Shihadeh, "Avicenna's Theodicy", 61-84.

${ }^{22}$ Ibn Sînâ, al-Shifâ', 416.

${ }^{23}$ Ibid., 416.; Khalil Sultan al-Qaraei, "A Study and Comparison of Evil from the Perspective of Augustine and Ibn Sina," Journal of Philosophical Research 5, No. 9 (2010): 96. 
Ibn Sînâ considers evil in essence to be almost the same as non-existent evil, which means the lack of goodness in a phenomenon or thing, and considers non-essential evil as a factor that prevents man from acquiring goodness and reaching perfection, and this the kind of evil can be the same evil that has been created as a pretext for the lack of goodness of God for man and the lack of a good system in the created world.

As for Swinburne's work, He mentions moral, natural, and compound evil, and considers the types of evil to be limited to these three. ${ }^{24}$

Swinburne considers moral evil to be the result of human abuse of their free will. In his theology, he emphasizes the value of free will in human beings and considers free choice between good and evil as a great good. Swinburne sees the justification of moral evil in goodness and believes that without the possibility of moral evil, not only will people be deprived of the great good of choosing between good and evil, but they will at most lose the opportunity to love God. Swinburne also acknowledges that the existence of moral evil is much greater in the presence of an omnipotent, absolute, and pure good God than when there is no god, but that the same moral evil exists in the presence of an omnipotent, and pure good God. It looks more like when there is no god. But the very existence of moral evil leads to a much higher purpose, and that is nothing but to provide the possibility of a special kind of complete love for God. ${ }^{25}$

In his definition of moral evil, Swinburne states that my perception of moral evil is all the bad things that human beings actually do when they either know that what they are doing is bad and especially wrong, or that they are negligent in doing it. What they believe is good, and especially obligatory, is ignored. ${ }^{26}$

From Swinburne's point of view, assuming we are free, we certainly have free and responsible choices. Humans can change themselves, others, and the world. Humans have opportunities to provide enjoyable feelings for themselves and others, and to pursue worthwhile and rewarding activities. Good for many actors who have the choice between good and bad requires a high probability of moral evil. Therefore, actors to choose between good and evil need to have some knowledge in advance, in this sense who want a series of things that they rightly believe are evil. ${ }^{27}$ Swinburne states, "I emphasize on the basis of voluntary defense that the natural possibility is moral evil, which is a necessary condition of abundant good, not actual evil itself. The occurrence of evil or its non-occurrence is beyond the control of God and is in the possession of $\operatorname{man}^{28}$

${ }^{24}$ Swinburne, Providence, 5.

${ }^{25}$ Ibid., 124.; Solgi Maryam, "A Comparative Study of Suhrawardi and Swinburne on the Problem of Evil," Andishe-e-Novin-e-Dini 14, No. 54, (2008): 150.

${ }^{26}$ Swinburne, Providence, 5-6.

${ }^{27}$ Gh. Pourhassan and H. Eskandari Damaneh, "Comparison of Motahhari and Swinburne's Views on the Problem of Evil," Philosophy of Religion (Nameh Hekmat) 12, no. 2, (2014): 14.

${ }^{28}$ Swinburne, Is There a God?, 159. 
Plantinga states: According to Swinburne, the core of the theory of divine justice in dealing with moral evil should be "voluntary defense". But if human beings are free and responsible, the possibility of moral evil will be necessary. The creation of creatures capable of doing good deeds is to have power over human deeds as well. God cannot give human beings the power to do evil deeds, but He prevents them from doing so from the beginning. Only by removing authority can evil be prevented..$^{29}$

Swinburne considers moral evil to be entirely under the sphere of human will and free will, which God has no role in motivating the human will to do. In other words, Swinburne believes in the complete free will of man that with this free will he can do good and also can cause evil by abusing and crookedness. Swinburne considers the existence of moral evil in the world and its creation by man as one of the reasons for the existence of absolute free will in man, which, contrary to the previous view, does not play a role in determinism and supernatural forces.

This type of evil is the same events in the natural world as floods, earthquakes, storms, tsunamis, etc, which may always occur in different parts of the world and their natural roots go back to nature. In defining natural evil, Swinburne states that natural evil is all evil that humans did not intentionally create and that their occurrence was not the result of human negligence. Natural evil includes both physical and mental suffering, and it does not differ from humans and animals; all the effects of the suffering of patients, natural disasters, and unexpected events that result from human beings in their lives are natural evils..$^{30}$

Swinburne believes that God created natural evil to do good and writes that I will be there to show how natural evil makes many good things possible. Natural evil is the range of good desires that perpetrators have or increases their susceptibility to self-cultivation for agents such as humans who have freedom. ${ }^{31}$

Swinburne considers natural evil to be the opposite of moral evil, which, on the contrary, is a product of nature and human beings have no role in their creation, and human will is neutral in their creation. Of course, it should be noted that this view of Swinburne only includes a number of examples of natural evil. Otherwise, today with the spread of technology and human manipulation in nature, it has an important role in creating natural evil and has de-balanced it.

Swinburne considers the greed of human beings to gain more benefits that cause damage to nature and the environment as a compound evil. ${ }^{32}$ In fact, evil from Swinburne's

${ }^{29}$ Alvin Plantinga, The Nature of Necessity (Oxford: Clarendon Press, 1974), 166.

${ }^{30}$ Eleonore Stump, "Knowledge, Freedom and the Problem of Evil," International Journal for Philosophy of Religion 14, no. 1, (1983): 49-58. http://www.jstor.org/stable/40012592.

${ }^{31}$ Swinburne, Providence, 160.; Richard Swinburne, "Natural Evil," American Philosophical Quarterly 15, no. 4, (1978): 295-301. http://www.jstor.org/stable/20009727.

${ }^{32}$ Swinburne, Is There a God?, 162-163. 
point of view includes evil that is a combination of moral and natural evil, but its nature is natural and evil will is involved in its creation, such as cutting down trees that cause floods or fires or fire of forests by humans. This approach of Swinburne is an explanation of man's misplaced interventions in nature and disrupting its normal order and routine, which, because man interferes in it and upsets it out of balance, is therefore considered evil.

\section{Solutions to the Problem of Evil}

As a Muslim, Ibn Sînâ avoids dualism and the arguments surrounding it in justifying evil, and justifies evil in terms of its non-existence and relativity. On the other hand, Ibn Sînâ has stated that bestowing good on many is another evil solution. Ibn Sînâ believes that God is omniscient and that nothing is beyond the scope of His knowledge and power, and that His power dominates everything, and that if He wills, He creates everything and everything is created according to His wisdom. On the other hand, the existence of evil does not contradict the divine attributes such as omnipotent, pure benevolent and just, but the existing evils in the world are a means to achieve the many and necessary good deeds of this world. Ibn Sînâ's solutions to solve the problem of evil are:

Ibn Sînâ considers evil to be non-existent and does not attribute any essence to it. He states that evil has no essence, but evil is the lack of substance or lack of goodness for the state of substance. ${ }^{33}$ In this context, Shahid Motahhari states:

"This solution seeks to disprove the duality rather than to solve the problem of evil; according to this view, because evils are non-existent, they do not need a creator, so because there is a species in the world that is charity, then only a creator we have and the idea of polytheism and dualism is false". ${ }^{34}$

According to the above definition, all evils are non-existent. When we say "evil is non-existent", we do not mean that there is no such thing as "evil". As we know, there is blindness, deafness, disease, oppression, ignorance, disability, death, earthquake, and so on. And there is no denying the existence of these. Nor is it the case that because evil is nonexistent, then evil does not exist, then man has no duty, because man's duty is to fight evil and to study good, and because every situation is good and not bad, then the status quo must be satisfied. And he considered it the best possible situation. Rather, the point is that all of these are of the type of "non-existences" and "absences", and the existence of these is of the type of the existence of "deficiencies" and "gaps", and they are evil because they themselves are destruction and non-existence or deficiency and vacuum, or they are the source of

${ }^{33}$ Ibn Sînâ, al-Shifâ', 355.

${ }^{34}$ Morteza Motahhari, Divine Justice (Tehran: Sadra Publications, 1983), 162. 
destruction, non-existence, scarcity and emptiness, and the role of man in the essential evolutionary system of the world is to compensate for the shortcomings and fill the gaps. ${ }^{35}$

Those who have considered evil not as non-existent but as existential have often used it to deny the existence of God. On the other hand, considering evil as non-existent, this view is rejected and cannot be a reason to deny the existence of God.

Other than that, Ibn Sînâ considers another justification of evil in its relativity and believes that evils are not absolute and are relative because a phenomenon may be useful for one person or object and the same phenomenon may appear as evil for another person or object. As a result, evil is relative and not absolute, and may appear different in different situations. ${ }^{36}$

There are two types of evils; evils that are non-existent and evils that are existential and are bad because they are the source of a series of non-existent things. Evils that are non-existent, such as ignorance, helplessness, poverty, are real but non-existent attributes. Still, existential evils are bad because they are the source of non-existent things, such as floods, earthquakes, stings, and germs, which are undoubtedly relative badness. ${ }^{37}$

God's intention and purpose are, first and foremost, attributed to the existence, which is the aspect of the goodness of things, but from these evil beings arises that which is not the main purpose of God, but second and breadth, is the purpose of God. The goodness of a bee is that it has a sting to defend itself and the evil of its sting is for humans or other creatures. ${ }^{38}$

The relativity of evil places more emphasis on the analogy of a phenomenon and an object that is considered evil; if considered with other phenomena and objects, it is considered good. For example, a bomb blast in the mountains for mining, although it may destroy ants and some surrounding animals, can ultimately reveal a large number of mineral reserves for humans, which is not a case of discovering mineral reserves for humans, and on the other hand, because it destroys some animals and creatures, it is evil. Therefore, evil is a relative and comparative thing that may always vary in different situations.

Ibn Sînâ considers evil to be a necessity of the natural world and believes that this world would not be a novel world without the existence of evil because the world without evil was already created by God. ${ }^{39}$ Therefore, in his view, the existence of evil is an inherent feature of the present world. He states:

${ }^{35}$ Swinburne, Is There a God?, 159.

${ }^{36}$ al-Qaraei, "A Study and Comparison of Evil", 95-96. See also Shihadeh, "Avicenna's Theodicy", 61-84.

${ }^{37}$ Eskandian and Nezhadian, "Evil Thought and its Approaches", 109.

${ }^{38}$ Akram Khalili Nooshabadi, God of Love and the Problem of Evil: Description, Review, and Critique of the Theological Irenaeus and the Cultivation of the Soul of John Hick (Qom: Taha Cultural Institute, 2016), 22.

${ }^{39}$ Sayeh Meisami, "Ibn Sînâ's Philosophical Interpretation of Sûrat al-Falaq," al-Bayan: 
"If all the subsequent evils of the beings of the material world are removed, they will become the beings of the first kind, that is, the beings of the world of intellects, while the intellectual and celestial beings, who are pure good and pure light, were created before. They must be created, otherwise the burden of transcendence will be questioned. Therefore, either these creatures should not have been created or they should have become the first type, and both cases require the non-issuance of existential grace by the absolute grace, and this is not worthy of the Almighty God. ${ }^{40}$ He also states: "If the material world, which is inextricably linked with evil, was created in such a way that no evil is realized at all, it would no longer be a material world, but another purely good world". ${ }^{41}$

In Ibn Sînâ's view, the evil in the world is not only a violation of the good system; on the contrary, it is an inseparable feature of the current world system.

One of the most important arguments that has been made as a response to evil is the dominance of the charitable aspect over the evil of the universe. According to this idea, although there are some evils in the world and some of them, such as earthquakes and floods, are the product of nature and some, such as murder and slavery, are the result of human malice, but it should be noted that the good of the world is more than its evils.

Ibn Sînâ is also among those who consider one of the ways of evil to be the spread of abundance and charity to the evil and states: "Although the sum of evils, such as diseases in the universe, is many, it is not a majority, and domination is still with charity. It is evil that damages the primary perfections". ${ }^{42} \mathrm{He}$ also considers the evil that is considered as a defect for secondary perfections, although it is maximum, but he considers this evil not as an act of the doer but as a lack of action of the doer, which is due to lack of ability and talent, and believes that such an evil It does not indicate a complete lack of good.

In dealing with the problem of evil, thinkers fall into two categories; some, such as Plato, Augustine, Leibniz, and many Islamic philosophers, have tried to make the problem of evil a violation of the attributes of God by recognizing the existing system and offering various solutions and arguments. On the other hand, people like J.L. Mackie ${ }^{43}$ and William L. Rowe ${ }^{44}$, considering the evil as irrational, have stated it as a reason to deny the existence of God and have considered the problem of evil as a refuge for their atheism. From Plato

Journal of Qur'an and Hadith Studies 15, no. 1, (2017): 1-19. https://doi.org/10.1163/2232196912340043.

${ }^{40}$ Ibn Sînâ, al-Najâh, 675.

${ }^{41}$ Ibn Sînâ, al-Shifâ, 421.

${ }^{42}$ Ibn Sînâ, al-Ta lîqât, 422.

${ }^{43}$ J.L. Mackie, "Evil and Omnipotence", in Mind 64, (1955): 200-212.

${ }^{44}$ William L. Rowe, "The Evidential Argument from Evil: A Second Look," Daniel HowardSnyder (ed.), The Evidential Argument from Evil (Bloomington, IN: Indiana University Press, 1996), 262-285.; William L. Rowe, "Evil and Theodicy," Philosophical Topics 16, (1988): 119-132. 
and Augustine, he did not contrast evils with the divine attributes of benevolence, justice, and wisdom, and sought solutions to the problem of the evils.

Swinburne believes that despite evil we can achieve many good deeds and to achieve some good deeds, the existence of evil is necessary in the world. In fact, evil is necessary for achieving some good deeds, and small evil should not be preferred to great good. He believes that evils come into being in order to achieve superior goodness. He says about how the pure God can allow evil to happen. Swinburne believes that evil comes together in order to achieve superior goodness. He talks about how the pure God can allow evil to happen, so he states: if a god who is pure good allows a bad state like E to occur, then:

1. He must have the right to allow this to happen.

2. Allowing E to occur is the only morally probable way to achieve a good state like G.

3. God does everything else through which $\mathrm{G}$ can be obtained.

4. The value expected in prescribing $E$ is positive; that is, it is worth allowing the initial evil to occur. ${ }^{45}$

According to Swinburne, God does not allow evil to occur in the universe except because the existence of that evil is a source of good for man and by its occurrence, provides a lot of good for man. ${ }^{46}$ In fact, evil does not happen by divine will and If they happen, they have so much good and blessing with them that it should not be referred to as evil, but it should be considered as a lot of good from pure good.

Swinburne believes that the problem of evil is not the lack of many good states, and although God creates a lot of good, he can create more good things, for example, that death is not evil in itself, death is the end of a good state, that is, life. Death may be evil if it arrives late or causes great sorrow to others, but death itself is not evil. ${ }^{47}$ Swinburne, therefore, believes in a large number of evils, that is, bad and positive states that God can eliminate. ${ }^{48}$

From Swinburne's point of view, beauty is not achieved in detail. When we look at only one part of a painting, that part may not look beautiful to us, but when we consider the whole painting, then that we can see its true beauty, and it is with a holistic view that we can realize the ultimate beauty. The same is true of music, as a note cannot be so pleasing, but when the set of notes are put together in a certain order, then it can be uplifting and refreshing for us. ${ }^{49}$ From Swinburne's point of view, the universe is also mixed with good

${ }^{45}$ Swinburne, Providence, 3.

${ }^{46}$ Richard Swinburne, "Theodicy, Our Well-Being, and God's Rights," International Journal for Philosophy of Religion 38, No. 1/3, (1995): 75-91. http://www.jstor.org/stable/40020330.

${ }^{47}$ Maryam, "A Comparative Study of Suhrawardi and Swinburne", 155.

${ }^{48}$ Swinburne, Providence, p, 47.

${ }^{49}$ Ibid., 49. 
and evil, and without the existence of evil, this world will not have its supreme beauty, and the existence of evil is necessary for the good system of this world.

Another of Swinburne's solutions to the problem of evil is to create goodness and compassion for evil. Some might say that if sympathy is desirable in a situation of suffering, then it is better than a situation in which there is no pain at all, but Swinburne believes that a world with such suffering and such feeling is at least as good as a world without suffering and without foundation and emotion, because it is good for us to have a deep concern for others. Man can not worry about the condition of others unless something bad happens or is probably bad, if things are always good for humans, there will be no opportunity for deep worry. ${ }^{50}$

The worst evil must be defeated with the highest goodness. Only through the goodness of God can the terrible evil be overcome. They are equally disproportionate to human nature, sharing in the terrible evil and living close to loving God. Because closeness to God thus transcends relationships with any creature, entering into man's personal relationship with God gives meaningful constructive value and mean to horrific suffering. This result is consistent with this Christian intuition that [although] the forces of darkness are stronger than man, they do not tolerate God's goodness bestows on man. ${ }^{51}$

In his works, Swinburne has also offered a solution to the problem of moral evil. Swinburne argues that in order for human beings to cause or prevent moral evil, it is necessary for them to acquire knowledge, and if human beings are to acquire knowledge, natural evils must necessarily occur because certain knowledge of what will happen in the future can only be obtained by inferring from examples that occurred in the past. Suppose human beings seek to create a situation through their actions or ignorance that causes or avoids evil consequences in the long run. In that case, they must know the consequences of their actions to acquire knowledge, and the most certain knowledge can be obtained from the past history of man. ${ }^{52}$

According to Swinburne, by acquiring knowledge about moral evil, we can prevent them from committing subconsciously without being aware of the evil of these acts. He believes that acquiring knowledge is a fundamental way to prevent moral evil.

\section{Conclusion}

The problem of evil is a long-standing case that has always raised questions for man about God and the universe. Ibn Sînâ and Swinburne are among the philosophers

\footnotetext{
${ }^{50}$ A. Yazdani, "A Critique of Swinburne's Theological Theory of Divine Justice in the Problem of Evil," Collection of Islamic Philosophy and Theology 46, no. 2, (2014): 152.

${ }^{51}$ Nigel Warburton, The Alphabet of Philosophy, trans. Massoud Olya (Tehran: Ghoghnos Publications, 2010), 230.

${ }^{52}$ Ibid., 154.
} 
who have dealt with and discussed the problem of evil in their works. Swinburne has proposed theodicy to solve the problem of evil, but Ibn Sînâ has discussed this in various sections in his works and has explained the problem of evil. Ibn Sînâ considers evil to be a non-existent thing that has no essence and existence and is a lack of perfection. This view of Swinburne is also in conflict with Christian theology, because in the philosophy of Augustine and Aquinas, from which Swinburne was greatly influenced, evil is expressed as non-existent.

Both philosophers believe that the problem of evil cannot be considered a factor in denying God, because God is not the creator of evil, and it is man who creates evil by his own will. On the other hand, both consider the existence of evil as an inseparable necessity of this world, without which the good aspect of this world cannot be considered, and it is with the presence of evil that the goodness of the world is revealed. Both philosophers have considered the role of imperfection in the definition of evil and have considered evil as an imperfection that the object is inherently devoid of it.

Ibn Sînâ considered the types of evil to be limited to relative non-existent evil and in essence and believes that evil is a non-existent thing that does not exist and what is considered evil is also a relative thing that for different people may be a phenomenon of evil and the same phenomenon is good for another person. For example, rain can be good for a farmer who has been waiting for rain for a long time to irrigate his farmland, but the same rain is evil because it destroys the earthenware jars that put their jars in the open air to dry. Also, in terms of time, evil is a relative thing and it is possible that at one time it is considered an evil phenomenon, and the same phenomenon is considered good in another period. For example, a flood that is first considered evil for a person, if after cut it, we realize that it has taken a treasure from the mountain with itself, and it is no longer considered evil but good. Evil in itself refers to the non-existent aspect of evil and the lack of perfection in it, and evil is also referred to as factors that prevent a person from achieving good, and these factors can be sin, lust, or anything else. But Swinburne, unlike Ibn Sînâ, divides evil according to the origin of evil and attributes moral evil to man, natural to nature, and compound to both. Swinburne mostly considers evil to be the estimation of human will and free will, which can be created by human misuse. The origin of the division of evil is one of the important aspects in explaining the intellectual differences between Ibn Sînâ and Swinburne about evil.

In terms of evil solutions, Ibn Sînâ has stated that non-existence and relativism are evil solutions that Swinburne does not believe it. But both philosophers believe that evil is necessary for this world, and it is in spite of evil that charity finds meaning. On the other hand, the existence of evil is necessary for the acquisition of good, and the identity of many charities is not understood without the existence of evil, such as health and security, or that which is not achieved, such as self-sacrifice. In their works, Ibn Sînâ and Swinburne have tried to glorify the divine attributes of limitation by evil and have tried to show the existence of a minimal evil compatible with the existence of a just, wise and absolute benevolent Creator. 
Mukhammad Zamzami, et al.: The Logical Problem of Evil in Islam and Christianity

\section{References}

Aei, Khalil Sultan. "A Study and Comparison of Evil from the Perspective of Augustine and Ibn Sina." Journal of Philosophical Research 5, no. 9, (2010).

Alizamani, Amir Abbas and Hashemi, Fateme Sadat. "Augustine's Theory on the Problem of Evil and Its Critique from Ibn Sina's Perspective." Avicennian Philosophy 19, no. 54, (2016).

Beheshti, Ahmad. Tajrîd. Qom: Book Garden Institute, 2010.

Lataster, Raphael. "On Richard Swinburne and the Failings of Christian Theistic Evidentialism." Literature and Aesthetics 26, (2016).

Leftow, Brian. "Swinburne on Divine Necessity", in Religious Studies 46, No. 2, (2010). http://www.jstor.org/stable/25676934.

Mackie, J.L. "Evil and Omnipotence." Mind 64, (1955).

Maryam, Solgi. "A Comparative Study of Suhrawardi and Swinburne on the Problem of Evil." Andishe-e-Novin-e-Dini 14, no. 54, (2008).

Meisami, Sayeh. "Ibn Sînâ's Philosophical Interpretation of Sûrat al-Falaq." al-Bayan: Journal of Qur'an and Hadith Studies 15, no. 1, (2017).DOI: https://doi.org/10.1163/2232196912340043.

Motahhari, Morteza. Divine Justice. Tehran: Sadra Publications, 1983.

Nooshabadi, Akram Khalili. God of Love and the Problem of Evil:Description, Review, and Critique of the Theological Irenaeus and the Cultivation of the Soul of John Hick. Qom: Taha Cultural Institute, 2016.

O'Connor, David. "Swinburne on Natural Evil from Natural Processes." International Journal for Philosophy of Religion 30, no. 2, (1991). http://www.jstor.org/stable/40020283.

Plantinga, Alvin. The Nature of Necessity. Oxford: Clarendon Press, 1974.

Pourhassan, Gh. and Damaneh, H. Eskandari. "Comparison of Motahhari and Swinburne's Views on the Problem of Evil." Philosophy of Religion (Nameh Hekmat) 12, no. 2, (2014).

Rowe, William L. "The Evidential Argument from Evil: A Second Look", in Daniel HowardSnyder (ed.), The Evidential Argument from Evil. Bloomington, IN: Indiana University Press, 1996.

Rowe, William L. "Evil and Theodicy." Philosophical Topics 16, (1988).

Sadeghi, Maryam. "The View of Three Muslim Wise Men on the Issue of Evil." Sinai Philosophy: Quarterly Journal of the Seventeenth Year (2013).

Shihadeh, Ayman. "Avicenna's Theodicy and al-Râzî's Anti-Theodicy", in Intellectual History of the Islamicate World 7, no. 1, (2019).DOI: https://doi.org/10.1163/2212943X-00701004.

Sînâ, Ibn. al-Ishârât wa al-Tanbîhât. Qom: Ayatollah Marashi Najafi Library, 1993.

Sînâ, Ibn. al-Najâh, ed. Mohammad Taghi Daneshpajooh. Tehran: University of Tehran Press, 1986. 
MIQOT Vol. 45 No. 1 January-June 2021

Sînâ, Ibn. al-Ta lîqâtt, ed. 'Abd al-Rahmân Badawî. Qom: Islamic Media School, 1982.

Spinoza, Baruch. Ethics, translated by Mohsen Jahangiri. Tehran: University Publishing Center, 1997.

Stump, Eleonore. "Knowledge, Freedom and the Problem of Evil." International Journal for Philosophy of Religion 14, no. 1, (1983). http://www.jstor.org/stable/40012592.

Swinburne, Richard. Providence and the Problem of Evil. Oxford: Oxford University Press, 2008.

Swinburne, Richard. "Natural Evil." American Philosophical Quarterly 15, no. 4, (1978). http:/ /www.jstor.org/stable/20009727.

Swinburne, Richard. "Theodicy, Our Well-Being, and God's Rights", in International Journal for Philosophy of Religion, 38, No. 1/3, (1995). http://www.jstor.org/stable/40020330.

Warburton, Nigel. The Alphabet of Philosophy, translated by Massoud Olya. Tehran: Ghoghnos Publications, 2010.

Yazdani, A. "A Critique of Swinburne's Theological Theory of Divine Justice in the Problem of Evil", in Collection of Islamic Philosophy and Theology 46, No. 2, (2014). 